\title{
The Effectivity of Snakes and Ladders Game Media To Improve English Vocabulary of Children
}

\author{
Mutiara Wulansari, Nur azizah \\ Yogyakarta State University, Yogyakarta, Indonesia \\ e-mail: mutiara.wulansari2016@student.uny.ac.id
}

\begin{abstract}
We know that media can help the development of children. For that reason, media is needed to facilitate learning of children in early childhood. This research is intended to know the effectivity of snakes and ladders game media in order to improve English vocabulary of children. This research is conducted to 4 to 5 years old children. This research uses one group pre-test post-test research design. This research uses observation as a technique to collect data. The analysis technique used in this research is Wilcoxon SignRank test. Based on the research, snakes and ladders media is considered effective to improve English vocabulary of 4 to 5 years old children. The effectivity based on analysis of pre-test and post-test data. The data analysis shows significance value of 0.01 for English vocabulary and 0.00 for had motor which are less than 0.05 which means that the Ho is rejected and Ha is accepted. It also means that there is a significant improve of English vocabulary before and after using the snakes and ladders game media. This snakes and ladders game media can be used by teacher as a learning alternative to improve English vocabulary of 4 to 5 years old children.
\end{abstract}

Keywords: $\quad$ Snakes and Ladders Game, Media, Children

\section{INTRODUCTION}

Language skill development in kindergarten is an important matter because language is used to think, observe, speak, read, and write. Language is developed as a way to reveal simple thought accurately, both to communicate effectively and to raise interest in order to speak Bahasa Indonesia correctly. Musfiroh (2005: 6) says that language development of a child includes the development of phonologic (to know and produce sound), vocabulary, semantic and meaning, syntax or sentence construction, and pragmatic or the use of language for communication according to convention norm. There are two steps of language acquisition of children, which are first language acquisition and second language acquisition (Sanjaya, 2009: 37).

According to the Department of National Education in Ministry of National Education
Number 22 Year 2006 about skills that should be owned by Indonesian students is to understand and reveal information, thought, feeling, and to develop knowledge, technology, and culture by using English. A tool used to communicate in order to access information and tool used to nurture interpersonal relationship and trade information in English. Vocabulary understanding is one of the components in language learning.

Learning a new language does not know any age limit, but in order to acquire fluent native-like English skill, it is more likely to happen if the learning is started as soon as when the child start to communicate verbally. A lot of children whose parents are from two different nations are capable of mastering both of their parents' first language fluently. It is because the children are directed to communicate using two languages. Learning second language since early childhood will not decrease a child's skills in using his or her own mother tongue, 
because children have a brain ability that let them master linguistic skills of various languages quickly.

It is based on the assumption that children can learn foreign language faster than adults (Sanstrock, 2007:313). A research conducted by Johnson and Newport (1991: 242) show that immigrant from China and Korea that live in America since they are 3 to 7 years old have better English skills compared to older children or adults. Other research states that children that master foreign language since early childhood have advantages in term of flexible intellectual, academic skills, language, and social (Mustafa, 2008: 54). Other than that, children will be more ready to enter social contexts with various languages and cultures. When they become adults, children will become human resources that have quality and achievement. Other than that, children will know how to appreciate and understand language and culture they learned since early childhood. It is because the children have bigger access toward foreign language and culture.

Learning in Early childhood education has to be presented by playing, interestingly, and by using interesting game media. It is in accordance with the principles of learning in early childhood education which are "learning by playing" and "learning while playing". For that reasons, learning is created and designed in such a way that children will be interested to follow the English leaning which is also hard motoric of the children. Playing is a very important activity for children. Playing gives the element of joy and happiness to children. Playing gives opportunity for children to solve the problems they experience. Playing is a way of children to imitate others and behaviors of adults in order to achieve maturity (Purboyo, 2004: 53).

Playing is useful for children to learn how to communicate well with their friends in putting forward their thought and feeling or to understand what is spoken (Purboyo, 2004: 73). Playing is also a media for children to learn the culture of social roles, and the roles of gender that occur in society. Based on the background, it is clear that English and hard motoric need to be taught since early childhood and should be delivered with interesting method and media. In fact there are still many children who have not been able to master the English vocabulary well at bilingual schools. here are still many children with pronauncation that are not good. The researcher is interested to conduct a research about "the effectivity of snakes and ladders game media to improve English vocabulary of children with 4 to 5 years in age".

\subsection{Learning Media}

AECT (Association of Education and Communication Technology, 1977: 50) states that media or material is a software that contains of messages or information related to education that is usually presented by using tools. Kempt \& Dayton in Arsyad (2007: 19) further states that learning media can fulfill three main functions if the media is used for personal, group or group of listeners in big number to 1) motivate interest or action, 2) present information and 3) give instruction. Principles of psychology that need to be considered in selecting and using media are as follow (Arsyad, 2007: 7274): 1) motivation, 2) individual differences, 3) learning purpose, 4) content organization, 5) preparation before learning, 6) emotion, 7) participation, 8) feedback, 9) reinforcement, 10) practice and repetition, 11) implementation.

Teaching vocabulary to children in early childhood can be through media. It is intended to make it easier for children to remember the material and avoid boredom. Not only that, a research also says that video game or a game can be beneficial for education and physical activity (Carlos, 2016: 14). Kasey (2013: 6) further reveals that playing by using media can give effect towards information processing.

\subsection{Games for Children in Early Childhood}

Children like free atmosphere with no pressure to interact with their friends and to play. For children, playing is viewed as a natural activity of children in acquiring experiences, a tool to find creativity, and a facility to develop intelligence (Ismail, 2006: 8). According to Hughes (1999), an expert in children's development states that playing is different with learning and working.

Playing is an activity that helps to achieve complete development, both physically, intellectual, social, moral, and emotional. Game means something used to play; goods or something played. Playing is an important thing for children. Principally, children learn through playing. "teachers, parents, and administrators need continued support in their efforts to include play in the curriculum and defend its use to those not as 
knowledgeable in early childhood education" (Brewer, 2007: 142).

Playing is one of learning principles of children in early childhood. Learning activity of children in early childhood should be managed with playing so that the children are happy and comfortable. Learning activity can be fun if it is done with a game. Hurlock $(1978,134)$ states that game is a process of physical or physic activity that is fun and enjoyable. Similar to the statement above, Andang Ismail (2006: 5) states that through playing activity, children can acquire learning that consists of cognitive, social, emotion, and physical development aspects. Through playing activity, children are stimulated to develop in general, either thinking development emotionally or socially. Wright (1984: 50) also says that playing game is a good way to learn vocabulary, especially in language class. By using game, teacher can make create many kinds of contexts where the students have to use language to communicate, trade information and express themselves.

\subsection{Snakes and Ladders Games}

Snakes and ladders game is a board game played by two or more children. The board game is divided into squares and consists of ladders and snakes in several squares. There is no standard in snakes and ladders game. Each person can create their own board with different number of squares, snakes and ladders (Agus N. Cahyo, 2011: 106). Ladder snakes are games that use dice to determine how many steps a piece has to go through. This game is included in the category "board game" or board game similar to the game monopoly, halma, ludo, and so on. The board is a picture of plots consisting of 10 rows and 10 columns with numbers $1-100$, as well as pictures of snakes and stairs. (M. Husna A, 2009: 145).

Snakes and Ladders is a popular game for children in many countries of the world. It is easy to make from basic materials and can be adapted to suit many learning situations. Definition of snakes and ladders according to Anjani (2012: 52), snakes and ladders is a board game played by two or more children. Within the board game, there are small squares and in several squares there are snakes and ladders that are connected to other squares. This game can be used for every learning subjects and every class, because the students just have to answer questions through the game.

\subsection{English Vocabulary of Children in early childhood}

Diamond (2006: 65) explains that vocabulary is the knowledge of words and word meanings. Similar to the explanation, Tarigan (1993: 3) words in English is called vocabulary, which is set of words owned, understood and then used to construct sentences by someone.

Other than that, Davies (2000: 60) also states that vocabulary is a set of words used either by someone as individual or groups to express thought and feeling in several aspects of life and main aspect of new vocabulary is to interpret word, to use in communication, pronunciation, spelling, and grammar. Cox (1996: 61) explains that "vocabulary development of a school age child may range from 2.500 to 8.000 words and will improve dramatically through the elementary years. Teachers can support vocabulary."

It is stated by Tomkins (1995: 44) that language learning has to be based on how children learn and how language is learned. Teacher has to give opportunity to students to find their learning style. First, the students have to be taught in oral and writing forms. Second, students have to get opportunity to imitate the language forms. Nation (2001: 107-108) further explains 3 procedures in teaching vocabulary, they are: recycled words, the second-hand cloze, dan the vocabulary interview. Blachowicz (1996: 7) also explains "learning new words as we have new words as we have experience is one of the most durable and long lasting ways to develop a rich vocabulary". Blachowicz (1996: 7) further explains that vocabulary learning occurs when students are active in finding the words related to experience or each other.

Nation (2001: 17) further explains that in vocabulary learning, teacher should keep close looks on these criteria: 1) the words have to be interested for the students, 2) the words should make the students pay attention to the form, meaning, or how to use the words in sentence, 3 ) the words have to allow repetition to happen. Similar to the explanation, Keraf (2009: 64) also states that childhood is the most important time to widen the range of vocabulary especially the ability of concrete nomination. For example, nowadays children only need terms to mention the words apart, for example through a game.

Suhartono (2005: 81) states that the acquisition of first language is the first language obtained and 
understood by children in life and communicating in their environment. Early childhood will get a second / foreign language after the child has first language. The second language of Indonesian children is generally a foreign language. The acquisition can be received from informal and formal education.

Suhartono further stated that efforts to introduce and add to the vocabulary of the second language of children are needed so that children have broader knowledge and insight. The introduction of a second language for early childhood has a variety of strategies. We recommend that the first type of word be introduced is a noun, then followed or continued to other types of words, namely verbs, adjectives, and others (Suhartono, 2005: 191). Learning English from an early age has an important role stated by Mustafa (2007: 20), that children who master foreign languages have advantages in intellectual, language and social academic skills. Learning English from an early age has an important role stated by Mustafa (2007: 20), that children who master foreign languages have advantages in intellectual, language and social academic skills. In addition, children will have readiness to enter a social complex with various cultures and religions.

The following are the achievement standards for English vocabulary learning for children aged 45 years: mention 1-10 numbers in English, mention and understand 4 colors in English, mention letters in AZ letters in English in an orderly manner, perform commands from the teacher in language English, imitating the sounds or sounds of animals (cats, dogs, chiken, etc.) exemplified by the teacher, correctly recounting 5 new words heard, mentioning> 3 English words correctly from 6 images, repeating sentences in the form of language English (thank you, I am sorry, etc.), expressing feelings of sadness, pleasure, fear, cold, heat, etc. while saying using English. Based on the explanation above, it can be concluded that learning English vocabulary for early childhood must be adjusted to the age and standard level of achievement of its development.

\section{METHOD}

This research is a pre-experimental design with one group pre-test-protest design. The field test subject consists of 16 children. This research uses observation in order to collect the data. The data are analyzed by using Wilcoxon Sign-rank test.

\section{RESULT AND DISCUSSION}

This research is conducted in order to know the effectivity of snakes and ladders game media towards the improve of English vocabulary of 4 to 5 years old children. This research is conducted to 16 children in four meetings. This research is conducted by using one group pre-test post-test design. This research is intended to improve English vocabulary and hard motoric of 4 to 5 years old children. The improve of children's skills is tested by using observational questionnaire before and after using guidelines book.

The implementation of this test is pre-test-posttest experiment. Within the pre-test, the children are observed by using cards for the improve vocabulary English. The cards contain pictures of goods and picture ilustration in English. Within this pre-test, the children are given as much as seven opportunities to take a card, it is meant to be the same as snakes and ladders game media where the children also have opportunities and obstacles.

The post-test is conducted by playing this snakes and ladders game. Each game is played by four children. Both results can be used to count the pre-test and post-test. Determination whether there is difference in English vocabulary skills before and after using the snakes and ladders game media can be identified by conducting differential test using SPSS. The hypotheses for differential test of English vocabulary before and after using game media are as follow:

Ho : There is no difference in English vocabulary skill before and after using the snakes and ladders game.

Ha : There is difference in English vocabulary skill before and after using the snakes and ladders game.

Table 1 Wilcoxon Sign-Rank test

\begin{tabular}{cc}
\hline & $\begin{array}{c}\text { Post-test- } \\
\text { Pre-test }\end{array}$ \\
\hline $\mathrm{Z}$ & $-3.553^{\mathrm{a}}$ \\
Asymp.Sig.(2-tailed) & .000 \\
\hline
\end{tabular}

Based on table 1, it is found that the result of Wilcoxon Sign-rank test has significance value of 0.01 , which is less than 0.05. It means that the Ho is rejected and $\mathrm{Ha}$ is accepted. It also means that there is a significant difference between English vocabulary skills. 
Table 2. Description of Pre-test Dan Post-test Data

\begin{tabular}{llll}
\hline & $\begin{array}{l}\text { Average } \\
\text { score }\end{array}$ & $\begin{array}{l}\text { Maximum } \\
\text { score }\end{array}$ & $\begin{array}{l}\text { Minimum } \\
\text { score }\end{array}$ \\
\hline $\begin{array}{l}\text { Pre- } \\
\text { test }\end{array}$ & 20.06 & 24 & 14 \\
$\begin{array}{l}\text { Post- } \\
\text { test }\end{array}$ & 28.88 & 34 & 22 \\
\hline
\end{tabular}

It is also strengthen with descriptive analysis in table 2.1 with improved average from 20.06 into 28.88. Based on this descriptive analysis, it can be concluded that English vocabulary skill is improved after using snakes and ladders game. Effectivity of snakes and ladders game media to improve English vocabulary shows positive influence. It is showed by the result of experiment conducted to 16 children in EL GENIO.

The result of class pre-test-protest experiment

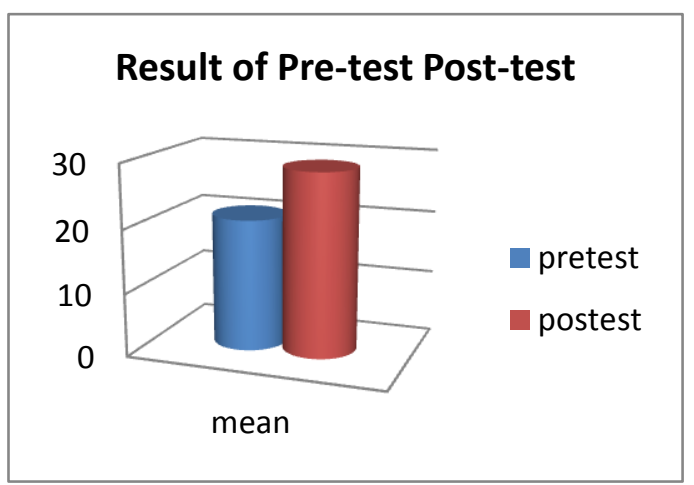

shows that English vocabulary improves from 20.06 into 28.88. It is in accordance with the theory of Mayke S (2001: 39-43) who also adds about the benefits of playing to optimize children's development, including: 1) benefits of playing for physical aspect development, 2) benefits of playing for social aspect development, 3) benefits of playing for emotional or personality aspect development, 4) benefits of playing for cognitive (language) aspect development.

A research conducted by Wohlwend (2016) in which the result shows that children are interested to media knowledge while playing and giving subtle improvisation to dialogues and action in story by enriching continuous playing theme and giving the children access to socialize in playing group. This research introduces letters by playing. Another similar research is conducted by Leif Marklund \& Elza Dunkels (2016: 8) digital playing as a facility to develop literacy and strength of children, using online ethnography study of Swede preschool teacher discussion in informal online forum. It is important for preschool teacher to discuss how to develop literacy.

A research conducted by Katy, Hisric, and Blanchard, Jay (2009: 10) discusses about digital media and potential impact towards literacy skills development that emerges for children. While the impact of digital media exposure towards the emergence of literacy development of children are mostly unknown, it become a significant problem, because more young children all across the world are observing and using various kind of digital media in preschool, home, and their community

\section{CONCLUSION}

Snakes and ladders game media is considered effective to improve English vocabulary of 4 to 5 years old children in EL GENIO based on the experiment. The effectivity is acquired from results of pre-test and post-test analysis. Based on the test data analysis, it shows that the significance value is 0.01 for English vocabulary less than 0.05 where the $\mathrm{Ho}$ is rejected and $\mathrm{Ha}$ is accepted which means there is a significant difference in English vocabulary before and after using snakes and ladders game.

Snakes and ladders game media cannot be used in every school because this product can only be used in bilingual-based school. For teacher in early childhood education, with snakes and ladders game media can be used as media to improve English vocabulary of 4 to 5 years old children to they are comfortable and happy so that the English vocabulary can develop optimally. For next researcher, this research can be one of the references in constructing similar research by keeping close looks on the existed limitation in this research.

\section{REFERENCES}

[1] A.L., Hughes. (1999), Psikologi Anak (Children, Play, and Development), Jakarta, Penerbit Gramedia.

[2] AECT. (1997). The Definition Of Educational Terminology. Washington. DC: Association for educational Communication and Technology.

[3] Anjani, Citra Pratiwi. 2012. "Media Pembelajaran Permainan Ular Tangga". Diakses
pada 10 darihttp://pracitra.blogspot.co.id/2012/11/media pembelajaran- permainan-ular-tangga.html.

[4] Arsyad, A.(2007). Media Pembelajaran. Jakarta: PT Raja Grafindo Persada 
[5] Blachowicz, C. \& Fisher, P. (1996) Teaching vocabulary in all classroms. Columbus, Ohio: Englewood Clifs, New Jersey

[6] Brewer Ann Jo, (2007). Introduction to Early Children Education Preschool trough Prymary Grades. Pearson: Allin And Bacon.

[7] Cahyo, Agus N. 2011. Gudang Permainan Kreatif Khusus Asah Otak Kiri Anak. Jogjakarta: Flashbooks.

[8] Carlos M,C, Fermandez, Hector del C.(2016). The Benefit of Video Games for Educational and Physical Activity Approaches: A Systematic Review.Alicante: Journal of New Approaches in Educational Research vol. 5, Iss 2

[9] Cox, D.R \& Wermuth, N. (1996). Multivariate Dependencies-Model Analysis and Interpretation.London: Chapman \& Hall.

[10] Davies, Paul \& Pearce, Eric. (2000). Success in English Teaching. New York: Oxford University Press.

[11] Diamond, L \& Linda Gn.(2006).“Teaching Vocabulary". Retrieved 20th June, 2008.Grasindo

[12] Hsieh, Ru-Lan, dkk.(2016). The Impact Of Shot-Term Video Games On Performance Among Children With Development Delays: A Randomized Controlled Trial. San Francisco: journal biological science vol. 11, Iss 3

[13] Hurlock, Elizabeth B. (1978). Perkembangan Anak Jilid 1. Jakarta: Erlangga.

[14] Ismail, Andang. (2006). Education Games (Menjadi Cerdas dan Ceria dengan Permainan Edukatif). Yogyakarta: Pilar Media.

[15] Johnson \& Newport.(1991). Critical period effects on universal properties of language: the status of subjacency in the acquisition of a second language.Medline: 39(3):215-258.

[16] KATY, HISRIC \& BLANCHARD, JAY. (2009). DIGITAL MEDIA AND EMERGENT LITERACY. EARLY CHILDHOOD EDUCATION COMPUTERS IN THE SCHOOLS, V26 N4 P240-255

[17] Kementerian Pendidikan Nasional.(2010). Pedoman Pengembangan Program
Pembelajaran Di Taman Kanak-Kanak. Jakarta: Departemen Pendidikan Nasional RI.

[18] Keraf, G. (2007). Diksi dan Gaya Bahasa. Jakarta: PT Gramedia Pustaka Utama.

[19] L. Marklund \& E. Dunkels. (2016). Digital play as a means to develop children's literacy and power in the Swedish preschool. Swedia: An International Research Journal ISSN: 09575146 (Print) 1472-4421

[20] M, Husna. (2009). 100+ Permainan Tradisional Indonesia. Yogyakarta: Andi Offset.

[21] Mayke S. Tedja Saputra, 2001, Bermain, Mainan, dan Permainan, Jakarta, PT

[22] Musfiroh,T. (2005). Bercerita Untuk Anak Usia Dini. Departemen Pendidikan Nasional.

[23] Mustafa, B. 2008. Dari Literasi Dini ke Literasi Teknologi.Jakarta: Yayasan CREST.

[24] Nation, I. S. P. (2001). Learning Vocabulary In Another Language.Cambridge: Cambridge University Press

[25] Purboyo, K. (2004).Kak Seto Bermain Dan Kreativitas Upaya Mengembangkan Kreativitas Anak Melalui Kegiatan Bermain. Jakarta: Papas Sinar Sinanti. Pustaka Pelajar.

[26] Sanjaya, W. (2009). Strategi Pembelajaran Berorientasi Standar Proses Pendidikan. Jakarta: Prenada.

[27] Santrock, John. W. (2007). Perkembangan Anak.(Alih bahasa: Mila Rachmawati).Jakarta: Erlangga.

[28] Suhartono. (2005). Pengembangan Keterampilan Bicara Anak Usia Dini. Jakarta: Depdiknas.

[29] Tarigan,H.G. (1993). Tes Kosakata. Bandung: Angkasa.

[30] Tomkins, G. E., \& Hoskisson, K.(1995). Language Arts: Content and Teaching Strategies.

[31] Wohlwend, Karen E. (2016). Who Gets To Play? Access, Popular Media And Participatory Literacies. Literacy, Culture, \& Language Education, Indiana University, Bloomington, IN, USAISSN: 0957-5146 (Print) 1472-4421

[32] Wright, John \& Sons Ltd Kent GG. (1984) The psychology of dental care. Bristol: 55-63. 